\title{
COVID-19 and Sickle Cell Disease: a new challenging dilemma in an old disease
}

Manuela Freire Hazin-Costa 1

iD https://orcid.org/0000-0001-5564-555X

Ana Laura Carneiro Gomes Ferreira 2

https://orcid.org/0000-0001-9172-6162

Evelyne Nascimento Pedrosa 3

https://orcid.org/0000-0003-1178-8465

Flavia Anchielle Carvalho da Silva 4

iD https://orcid.org/0000-0002-6468-3694

\author{
Maria Suely Medeiros Correa 5 \\ (iD) https://orcid.org/0000-0003-1241-5361 \\ Ariani Impieri Souza 6 \\ (iD) https://orcid.org/0000-0002-7917-5983
}

\footnotetext{
1 Departamento de Medicina Clínica. Universidade Federal de Pernambuco. Av. Prof. Moraes Rego, 1235. Cidade Universitária. Recife, PE, Brasil. CEP: 50.670-901. E-mail: manuhazin@yahoo.com.br

2,4 Instituto de Medicina Integral Professor Fernando Figueira. Recife, PE, Brasil.

3,6 Faculdade Pernambucana de Saúde. Recife, PE, Brasil.

5 Universidade de Pernambuco.Recife, PE, Brasil.
}

\begin{abstract}
The authors bring reflections about people with sickle cell disease in the pandemic era. They comment on some common clinical situations in these two diseases which may delay or confuse the diagnosis of COVID-19 in patients with sickle cell disease. We consider that people with sickle cell disease are part of the risk group for the complications of COVID-19 and the topic should be addressed in the scientific literature.
\end{abstract}

Key words COVID-19, Sickle cell disease

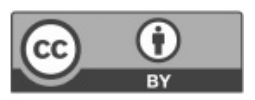




\section{Introduction}

More than 110 years ago, Sickle Cell Disease (SCD) has been scientifically described and since then the variability of clinical manifestations, its unfavorable outcomes and pathophysiology are still a challenge for health professionals and patients. ${ }^{1}$ Currently, the pandemic of the new coronavirus (Sars-Cov-2) has affected people with greater clinical vulnerability resulting in high mortality rates among individuals. ${ }^{2}$ Are SCD patients at a higher risk of COVID-19 adverse outcomes? And will the like-coronavirus clinical manifestations be more easily identified in SCD patients? These are still unanswered questions faced in the pandemic scenario regarding to the SCD population.

Chronic hemolytic anemia, signs of vessel occlusion with inflammatory tissue reactions, release of inflammatory cytokines and chemokines, tissue and coagulation factors are part of the physiology of SCD. ${ }^{1}$ In the context of COVID-19, there is still much to be known, but signs of cytokine storm and inflammatory tissue reactions with signs of procoagulation are reported in recent publications. ${ }^{3}$ These inflammatory conditions occur in both SCD and COVID19 infection.

The latest publications on COVID-19, refer to infection and dysfunction of the vascular endothelium as major events occur mainly in the pulmonary tract, but also could be present in other organs. This endothelium damage also appears in SCD patients and this is another reason to try to explain and understand SCD patients as a vulnerable population to COVID-19 complications. ${ }^{4-6}$

Would there be an overlap of inflammation from both diseases? Or inflammation would be itself a factor of greater severity for SCD patients? In addition, would inflammation be a clinical situation in which secondary signs and symptoms of SCD would be difficult to distinguish in SCD patients infected with COVID-19?

In this context, theoretical comparisons will be made here, so that new study proposals could be presented for SCD patients with COVID-19. It is known that patients with SCD are also at increased risk for infections associated with greater morbidity and mortality, being the most frequent cause of death by infection, when it is not accurately diagnosed and treated. ${ }^{1}$

Acute chest syndrome (ACS) is another feared urgency in SCD and like other viral infections, SARS-CoV-2 can also cause ACS in SCD patients. In a pandemic scenario, ACS may be more frequent and indistinguishable than pneumonia (PNA) because patients typically present sudden onset of lower-respiratory tract symptoms, including cough, dyspnea, and chest pain, and a new pulmonary infiltrate on chest radiograph, clinical aspects very similar from those with COVID-19. Early identification of these clinical manifestation will benefit affected patients, since ACS overlaps on COVID-19, it worsens the mortality rate among infected population. 7,8 COVID-19 infection in SCD population can potentially cause severe (pulmonary) complications, either by directly causing severe pneumonia or by triggering a VOC and/or ACS.9

Neurological manifestations in patients with SCD are well described and are presented mainly as stroke and headaches. 10 During the pandemic period of COVID-19, symptoms vary from non-specific headaches or dizziness to more specific such as seizures and cerebrovascular disease. 11 Even if these clinical aspects are not so frequent, it is important to know that probably they could worsen the neurological signs in SCD patients.

Cardiovascular manifestations in SCD patients are also well described (elevated pulmonary artery systolic pressure, pulmonary hypertension, left ventricular diastolic heart disease, dysrhythmia, sudden death). 12 Myocardial injury has been reported in affected patients with COVID-19 and this damage could worsen a previous cardiac disease. 13

In patients with $\mathrm{SCD}$, another complication is nephropathy (glomerulopathy, proteinuria, hematuria, tubular defects, and end-stage renal disease) and there are different pathophysiologic mechanisms, such as hemolysis and vascular occlusion. 14 In COVID-19 infection, acute kidney injury, proteinuria and rarely hematuria; there are also some reports in kidney histology showing acute tubular necrosis. ${ }^{15}$

Another important aspect of SCD and COVID19 infection is during pregnancy. Women and their fetuses represent a high-risk population during the pandemic of COVID-19. Pregnant women with SCD are associated with increased rates of obstetric, perinatal and clinical complications (early pregnancy loss, pulmonary embolism, miscarriage, preterm deliveries, higher rates of pain events and transfusion) with higher mortality and morbidity rates, 16 as we have published.17 The maternal and fetal outcomes of SARS-CoV-2 infections in pregnancy are also adverse and preterm deliveries, spontaneous abortion, thromboembolic events or intrauterine growth restriction have been also reported.18 In a recent case report, there was a favorable outcome of a pregnant woman with SCD and COVID-19 infec- 
tion. ${ }^{19}$ On the other hand, there are also case reports about the worst cases in pregnant women with COVID-19, to corroborate the idea that more studies are necessary to stablish and define clinical characteristics of these diseases altogether. ${ }^{20}$

We encourage to develop a practical guideline based on what have been published about COVID19 and what is already known about the SCD physiology. It may diminish unfavorable outcomes that we suppose could affect SCD patients, as we have classified them as a vulnerable population.

\section{References}

1. Piel FB, Steinberg MH, Rees DC. Sickle Cell Disease. N Engl J Med. 2017; 376 (16): 1561-73.

2. Pascarella G, Strumia A, Piliego C, Bruno F, Del Buono F, Costa F, Scarlata S, Agrò FE. COVID-19 diagnosis and management: a comprehensive review. J Intern Med. 2020; 288 (2): 192-206.

3. Ye Q, Wang B, Mao J. The pathogenesis and treatment of the 'Cytokine Storm' in COVID-19. J Infect. 2020;80(6): 607-13.

4. Tan CW, Low JGH, Wong WH, Chua YY, Goh SL, Ng HJ. Critically ill COVID-19 infected patients exhibit increased clot waveform analysis parameters consistent with hypercoagulability. Am J Hematol. 2020; 95 (7): 157-8.

5. Bikdeli B, Madhavan MV, Jimenez D, Chuich T, Dreyfuls I, Driggin E, et al. COVID-19 and Thrombotic or Thromboembolic Disease: Implications for Prevention, Antithrombotic Therapy, and Follow-up. J Am CollCardiol. 2020; 75 (23): 2950-73.

6. Kato GJ, Steinberg MH, Gladwin MT. Intravascular hemolysis and the pathophysiology of sickle cell disease. J Clin Invest. 2017; 127 (3): 750-60.

7. Claudio AM, Foltanski L, Delay T, Britell A, Duckett A, Weeda ER, Bohm N. Antibiotic Use and Respiratory Pathogens in Adults With Sickle Cell Disease and Acute Chest Syndrome. Ann Pharmacother. 2019; 53 (10): 991-6.

8. Chakraborty C, Sharma AR, Sharma G, Bhattacharya M, Lee SS. SARS-CoV-2 causing pneumonia-associated respiratory disorder (COVID-19): diagnostic and proposed therapeutic options. Eur Rev Med Pharmacol Sci. 2020; 24 (7): 4016-26.

9. Nur E, Gaartman AE, van Tuijn CFJ, Tang MW, Biemond BJ. Vaso-occlusive crisis and acute chest syndrome in sickle cell disease due to 2019 novel coronavirus disease (COVID-19). Am J Hematol. 2020; 95 (6): 725-6.

10. Hirtz D, Kirkham FJ. Sickle Cell Disease and Stroke. Pediatr Neurol. 2019;95:34-41.

Received on September 23, 2020

Approved on October 30, 2020

\section{Authors' contribution}

All authors designed the main conceptual ideas and contributed to the final version of the manuscript.

11. Asadi-Pooya AA, Simani L. Central nervous system manifestations of COVID-19: A systematic review. J Neurol Sci. 2020; 413: 116832 .

12. Gladwin MT. Cardiovascular complications in patients with sickle cell disease. Hematology Am Soc Hematol Educ Program. 2017; 2017 (1): 423-30.

13. Clerkin KJ, Fried JA, Raikhelkar J, Sayer G, Griffin JM, Masoumi A, Jain SS, Burkhoff D, Kumaraiah D, Rabbani L, Schwartz A. COVID-19 and Cardiovascular Disease. Circulation. 2020; 141 (20): 1648-55.

14. Hariri E, Mansour A, El Alam A, Daaboul Y, Korjian S, AounBahous S. Sickle cell nephropathy: an update on pathophysiology, diagnosis, and treatment. Int Urol Nephrol. 2018;50(6):1075-83.

15. Cheng Y, Luo R, Wang K, Zhang M, Wang Z, Dong L, Li J, Yao Y, Ge S, Xu G. Kidney disease is associated with inhospital death of patients with COVID-19. Kidney Int. 2020; 97 (5): 829-38.

16. Boafor TK, Olayemi E, Galadanci N, Hayfron-Benjamin C, Dei-Adomakoh Y, Segbefia C, et al. Pregnancy outcomes in women with sickle-cell disease in low and high income countries: a systematic review and meta-analysis. BJOG. 2016; 123 (5): 691-8.

17. Silva FAC, Ferreira ALCG, Hazin-Costa MF, Dias MLG, Araújo AS, Souza AI. Adverse clinical and obstetric outcomes among pregnant women with different sickle cell disease genotypes. Int J Gynecol Obstet 2018; 143: 89-93.

18. Dashraath P, Wong JLJ, Lim MXK, Lim LM, Li S, Biswas A, Choolani M, Mattar C, Su LL. Coronavirus disease 2019 (COVID-19) pandemic and pregnancy. Am J Obstet Gynecol. 2020; 222 (6): 521-31.

19. Justino CC, Campanharo FF, Augusto MN, Morais SC, FigueiredoMS. COVID-19 as a trigger of acute chest syndrome in a pregnant woman with sickle cell anemia. Hematol Transfus Cell Ther. 2020; 42(3): 212-4.

20. Zaigham M, Andersson O. Maternal and perinatal outcomes with COVID-19: a systematic review of 108 pregnancies. Acta Obstet Gynecol Scand. 2020; 99 (7): 823-9. 